Association for Information Systems AIS Electronic Library (AISeL)

Wirtschaftsinformatik Proceedings 2005

Wirtschaftsinformatik

February 2005

\title{
Vertical Integration and Bank Performance
}

Tom Gellrich

Johann Wolfgang Goethe University

Andreas Hackethal

Johann Wolfgang Goethe University

Markus Holzhäuser

Johann Wolfgang Goethe University

Follow this and additional works at: http://aisel.aisnet.org/wi2005

\section{Recommended Citation}

Gellrich, Tom; Hackethal, Andreas; and Holzhäuser, Markus, "Vertical Integration and Bank Performance" (2005). Wirtschaftsinformatik Proceedings 2005. 29.

http://aisel.aisnet.org/wi2005/29

This material is brought to you by the Wirtschaftsinformatik at AIS Electronic Library (AISeL). It has been accepted for inclusion in Wirtschaftsinformatik Proceedings 2005 by an authorized administrator of AIS Electronic Library (AISeL). For more information, please contact elibrary@aisnet.org. 
In: Ferstl, Otto K, u.a. (Hg) 2005. Wirtschaftsinformatik 2005: eEconomy, eGovernment, eSociety; 7. Internationale Tagung Wirtschaftsinformatik 2005. Heidelberg: Physica-Verlag

ISBN: 3-7908-1574-8

(C) Physica-Verlag Heidelberg 2005 


\title{
Vertical Integration and Bank Performance
}

\author{
Tom Gellrich, Andreas Hackethal, Markus Holzhäuser
}

Johann Wolfgang Goethe University

\begin{abstract}
This paper examines vertical integration and its impact on profitability and shareholder value in the global banking industry. We derive a measure for vertical integration using a sample of 859 banks from 9 Anglo-Saxon and European countries covering the timeframe 1997-2002. Our results suggest that banks either operating on highly integrated or highly disintegrated levels of vertical integration display superior performance figures and stock market evaluations. Additionally, vertically integrated banks show lower levels of firm risk. As our results suggest an interrelation between vertical integration and outsourcing, banks need clear determined strategies whether to engage into outsourcing activities or not.
\end{abstract}

Keywords: Vertical Integration; Bank Performance; Outsourcing

\section{Introduction}

Is vertical integration profitable? Vertical integration involves a variety of complex strategic decisions to be performed by the top-management of companies. Corporations and especially banks are concerned with the arbitrary question whether they should provide certain goods or services in-house or purchase them from outside vendors instead. This complex consideration can be boiled down to a plain question - make or buy? [Maho92, Mpoy03, QuHi94] - and what are potential effects on firm performance? Corporations and especially banks increasingly undertake considerations regarding their operational production structures and thus inevitably evaluate vertical integration or disintegration. Formerly highly integrated companies such as banks are becoming less integrated as they increasingly engage into divesting or outsourcing activities [Cald03, CaYo03].

The objective of this paper is to provide deeper insights into the issue of vertical integration in the global banking industry. What is the relationship between outsourcing and vertical integration, what are the consequences of different strategies regarding vertical integration and finally, how is a bank's performance impacted by different levels of vertical integration (or, in other words, what is the optimal size of a bank with regard to firm performance)?

The performance implications of vertical integration in banking have been debated to some extent. However, very little empirical research has been undertaken to de- 
termine whether and to what extent vertical integration influences banks' financial performance. In this study, we have introduced a first intra-industry measure for vertical integration in the global banking industry and examined the impact on financial performance.

This paper contributes to the actual discussion regarding the optimal strategic alignment of successful banks in the future. Should banks solely focus on their traditional core competencies [PrHa90], what is the role of outsourcing [FuMe99, QuHi94] and what are potential performance implications [GiRa00, Harr85, MaZa85, ReFr90]? Our paper provides a first coherent view between those different aspects, integrates "outsourcing" into the broader view of "vertical integration" in the global banking industry and evaluates potential performance implications. It suggests viable strategies for both scientists as well as practitioners in order to shape future successful banking organisations.

The paper is structured as follows: we provide the theoretical foundation of vertical integration, derive a set of hypotheses and give an overview of the current state of research. Thereafter we introduce the measure for vertical integration in the banking industry. The next section provides information regarding sample designs and conducted statistical tests. We then measure vertical integration and related performance effects. The paper closes with a discussion and conclusion.

\section{Literature Review}

Measuring vertical integration is central to the empirical investigation of performance implications of a banking strategy [Pale85]. Concepts of vertical integration have received extensive attention in the scientific community for more than the past 50 years. As Maddigan and Zaima [MaZa85] point out, one of the difficulties is to develop an appropriate empirical measurement which is widely accepted. Advantages and disadvantages and the respective implications on firm performance of different levels of vertical integration have received attention, both from scientists as well as from practitioners. A good overview is provided by Harrigan [Harr84]. Generally, at least three different measurement methods for vertical integration can be detected in the empirical literature.

One category reflects vertical integration by input-output models, a concept which is based on works by Leontieff [Leon51]. This concept is also employed by other authors [CaBr88, ClCa77, DaMo95, Madd81]. Maddigan [Madd81] praises this approach due to its network-characteristics as being more appropriate to conceptualize modern industrial production since a single processing chain is often too narrow. Major drawback of this concept is that the required data is difficult to obtain or especially in the banking industry not publicly available at all. 
A second category of literature measures vertical integration as the percentage of total production which is part of a company's vertical chain. This ratio is employed by Rumelt [Rume74]. Maddigan [Madd81] mentions two problems: the ratio can increase as the result of a horizontal merger and the data needed to construct the index requires a breakdown of the total value of production by product line, which is often not available in public.

The third most-widely referred approach is based on pioneering work by Adelman [Adel55], Gort [Gort62], and Nelson [Nels63]. The work has been continued and extended by Laffer [Laff69], Tucker and Wilder [TuWi77, WiTu84], Levy [Levy85], Reed and Fronmueller [ReFr90], and Görzig and Stephan [GöSt02]. The link between these studies is a similar approach towards measuring vertical integration. All studies employ a ratio of corporate product to corporate sales. The ratio is often termed "value-added to sales, VAS". According to Martin [Mart86] VAS is the most common measure of vertical integration in economic research. If a firm integrates forwards or backwards (i.e. acquiring customers or suppliers) the VAS increases and vice versa. While this index has considerable appeal because of its computational properties, several authors [DaMo95, DaRa94, Madd81, ReFr90] mention potential drawbacks of this concept: the ratio might be influenced by a company's profitability and the ratio is sensitive to the stage in the vertical chain at which the firm operates (i.e. it can be greater if the firm is nearer to a primary level of production). On the other hand this ratio has the advantage of ease of calculation [Madd81, ReFr90] since all computations are based on publicly disclosed information by the individual firms. Although we are aware of some conceptual drawbacks we have chosen to construct a measure of value added to sales (VAS) for the banking industry being introduced in section 3 .

Buzzell [Buzz83] and Maddigan and Zaima [MaZa85] state that higher profitability can be observed for firms with high values of vertical integration, measured as VAS. A variety of authors [Buzz83, ReFr90, Vese78] provide evidence of the problems that might arise when extraneous factors (e.g. industry, firm size, etc.) that affect performance are not controlled for. Harrigan [Harr85] suggest that a comprehensive investigation of strategic factors is hampered by the high level of aggregation of data used in these studies. Several scientists relate the degree of vertical integration to industry-specific factors such as number of competitors, number of firms on upstream or downstream production levels, demand uncertainty or potentials for synergies with adjacent strategic business units (for a good overview see [DaRa94, Harr85, Lieb91, Mart86]). These are external determinants which can not be influenced by a specific company. In our paper we propose a different perspective by analyzing different levels of vertical integration in a specific industry and relating this integration to firm performance.

In a corporate strategy study covering multi-industry aspects, Rumelt [Rume74, Rume82] found vertically integrated firms to be the poorest performers of all companies in the sample. In a single-industry study covering the forest products industry, D'Aveni and Illinitch [DaI192] found vertically integrated companies 
bear a higher risk of bankruptcy. Vertical integration can influence companies not to purchase input resources at the lowest possible prices [Qui+90]. Mahoney [Maho92] suggests other costs to be associated with high levels of vertical integration. Along similar lines of argumentation and findings other scientists to recommend outsourcing strategies or form strategic alliances [Harr85] or disintegrate [Barr88].

Contrasting this viewpoint, a variety of authors point out the incentive to vertically integrate positively impacts cost structures [JoHi88], reduces transaction costs [JoHi88, Maho92, Will71, Will79], eliminates upstream market price distortions [VeGr71, West81], decreases asymmetric information [Green74], or protects access to proprietary technology [JoHi88]. Vertical integration can also have positive impact on a firm's profit by allowing price discrimination [Perr80], creating barriers to entry [SaSc83], or enhancing a company's power over suppliers and buyers [Port80].

Controlling for industry, firm size and strategic posture, Reed and Fronmueller [ReFr90] find minor and non-significant performance differentials between vertically integrated and non-vertically integrated firms. They conclude that the strategy of vertical integration in itself does not produce superior levels of profitability, growth and does not impact a firm's risk level. Controlling for industry effects and economies of scope and scale D'Aveni and Ravenscraft [DaRa94] find that vertically integrated lines of business display performance increases but show higher production costs, thus resulting in only marginally better profitability than non-integrated lines of business in the same industry. Higher production costs can be associated to backward vertical integration, suggesting insulation from market pressures. Forward vertical integration is associated with lower transaction costs. Fixler and Siegel [FiSi99] analyze outsourcing in the service sector and conclude that outsourcing has reduced service sector productivity in the short run. Using a sample of the manufacturing industry, Gilley and Rasheed [GiRa00] find that firms pursuing more intense outsourcing strategies do not experience significant, direct performance impacts on the overall firm. They indicate that it might well be that sourcing activities have an effect on the individual functional areas in which they occur. Analysing data from the German manufacturing industry, Kinkel and Lay [KiLa03] find that higher degrees of vertical integration result in superior levels of firm performance, innovation activities and flexibility.

In sum, this discussion leaves the question, what impact a firm's vertical integration in this case of banks on firm performance has. We address this issue by using a unique set of data extracted from Bankscope and applying a measure of vertical integration proposed by Tucker and Wilder [TuWi77]. 


\section{Measuring Vertical Integration}

Applying VAS, Tucker and Wilder [TuWi77] calculate value added of a specific firm as the sum of depreciation and amortization, interest expense, labour, incentive, pension and retirement expense, income taxes, net income, and rental expense.

Obviously, adaptations are to be made for our sample covering the banking industry. Depreciation and amortization are replaced by Loan Loss Provisions (LLP), labour expenses include expenses for incentives and pensions. Rental expenses can not be calculated since they are not publicly available. We calculate the value added as the sum of loan loss provisions (LLP), fixed charges and interest expenses (IE), labour expenses (LE), income taxes (IT), and net income (after tax) (NIAT). Thus, the value added of firm $\mathrm{i}$ in a given year $\mathrm{j}$ is calculated as:

$$
V A_{i, j}=L L P_{i, j}+I E_{i, j}+L E_{i, j}+I T_{i, j}+N I A T_{i, j}
$$

Similar to Tucker and Wilder [TuWi77] our vertical integration index for firm i in year $\mathrm{j}$ is then defined as the ratio of value added to net sales (raw vertical integration index, RVI):

$$
R V I_{i, j}=\frac{V A_{i, j}}{\text { Sales }_{i, j}}
$$

Sales for bank $\mathrm{i}$ in year $\mathrm{j}$ are defined as the sum of Interest Income (IIn), Fee Income (FIn), Commission Income (CIn), Trading Income (TIn), and other income (OIn):

$$
\text { Sales }_{i, j}=I \operatorname{In}_{i, j}+F \operatorname{In}_{i, j}+C \operatorname{In}_{i, j}+\operatorname{TIn}_{i, j}+O \operatorname{In}_{i, j}
$$

In accordance with Tucker and Wilder [TuWi77] we eliminate the effect of static differences and trends in profitability and effects of changing depreciation and other tax laws, we construct the Adjusted Vertical Integration Index (AVI) for firm $\mathrm{I}$ in year $\mathrm{j}$ as follows:

$$
A V I_{i, j}=\frac{V A_{i, j}-\left(N I A T_{i, j}+I T_{i, j}\right)}{\text { Sales }_{i, j}-\left(N I A T_{i, j}+I T_{i, j}\right)}
$$

The AVI can be viewed as a more conceptually sound method of measuring trends in vertical integration, since it removes the effect of trends in profitability and taxation [TuWi77]. For this paper we will use AVI to measure vertical integration. 


\section{Theories and Hypotheses}

Economists and strategic management researchers agree that there are many possible motives for vertical integration [Maho92]. Integration may be induced by transaction costs, imperfect competition, imperfect information and a variety of other factors [Lieb91, Maho89]. Also macroeconomic variables such as industry characteristics and structures can influence vertical integration [Harr85, Mart86, Mpoy03, ViWa91]. Vertical integration can be defined as the number of activities along the value chain that are performed within a single company [Mpoy03] or the stages of production that are under the legal and financial control of a single firm. Firms can use a variety of strategic levers and forms of cooperation with other companies which impact their vertical integration. Apart from mergers and acquisitions or establishing completely new firms, joint ventures and other hybrid forms of cooperation with other companies can be undertaken as well as outsourcing of business areas or decisions to divest. As motivated above, this paper solely focuses on the interrelation between vertical integration and outsourcing and the impact on the banking value chain and performance.

For this study we follow Bartell [Bart98]: "In its most vanilla, operational terms, outsourcing is synonymous with contracting out, any or all of an in-house function to a third party. [...] In sum, outsourcing is any change in the provision of goods and services from in-house capabilities to a third-party." Thus, outsourcing directly influences a firm's structure of vertical integration.

Hypothesis 1: Outsourcing and vertical integration are directly interrelated. Banks engaging in outsourcing activities have a lower level of vertical integration.

Outsourcing offers a variety of advantages. One of the most cited [Luk +02$]$ is the potential for savings and the flexibilization of formerly fixed cost structures, directly influencing a firm's financial performance.

Hypothesis 2: Outsourcing and profitability are positively correlated. We expect that banks actively engaging in sourcing activities show a positive financial performance in terms of ROE and operating ROE.

In principal, institutional economics and production theories provide a valid framework to analyze the rationale behind a company's decision to vertically integrate or disintegrate.

Resource-based theory (RBT) views a firm as a collection of productive resources $[\mathrm{Che}+95]$. A company's growth and success are interrelated to utilization of its best resources. Barney [Barn91] and Cheong et.al. [Che+95] attribute four criteria to the resources if they are to provide sustained competitive advantage: Value, rareness, imperfect immutability and non-substitutability. Grant [Gran91] states that a resource-based approach to strategy is concerned not only with the deployment of existing resources, but also with the development of the firm's resources 
and capabilities. In order to fully exploit the firm's existing resources and capabilities, a firm needs to focus on its core competencies. Thus external acquisition of complementary resources and capabilities may be necessary to fill the difference between a firm's desired and actual capabilities. According to RBT, banks can reach a superior level of production or performance when the best resources are leveraged in-house and all complementary and non-core activities are sourced externally. This implies that firms can not cover all stages of the value chain; instead corporations focus on their core capabilities and use external vendors to supply complementary goods.

Hypothesis 3: Focusing on core competencies implies less vertically integrated production structures and leads to superior competitive advantage. Less vertical integration thus results in superior financial performance in terms of ROE and operating ROE.

Transaction cost economics (TCE) was introduced by Coase [Coas37] and developed by Williamson [Will75, Will79, Will81]. Principally, TCE focus on two types of cost: Production cost and transaction cost. Economically successful companies maintain their position through a superior balance of production cost against transaction cost. Thus, focus is on production and efficient management of transactions. These are defined as exchanging goods or services within the organization or between the organization and the external world. Transaction costs increase as a result of three factors: asset specificity of the individual resource to the firm, uncertainty regarding the environment and infrequency regarding the commonness. A first intuitive suggestion could lead to the idea that less direct financial and legal control results in higher transaction costs. This suggestion is also supported by the agency cost theory (ACT), developed by Ross [Ross73] and perpetuated by Jensen and Meckling [JeMe76]. ACT focuses on determining the most efficient contract that governs the relationship between a principal and an agent. The choice between a behaviour-based contract (e.g. hierarchy, vertical integration) and outcome-based contract (e.g. market, vertical disintegration) depends on the agency costs, which are costs incurred as a result of discrepancies between the objectives of the principal and those of agents. Thus, agency costs are the sum of the principal's monitoring costs, bonding costs by the agent and the residual loss of the principal. Agency costs increase when principals exert less direct control over the agent. ACT suggests that firms are more prone to vertically disintegrate when agency costs are low and contract enforcement between principal and agent is easy.

Banks need to strategically determine whether the appropriate governance structure for a transaction is a market (i.e. less control over resources) or a hierarchy (i.e. increased control over resources). Vertical disintegration implicates lower production cost but higher transaction cost and risks arising from negotiation, monitoring and enforcing contracts with other, external levels of production [Che+95]. Each of these factors raises the effort and cost as well as potential risks of structuring an agreement between an organization and external producers that 
will assure the successful completion of the contract and its future enforcement. TCE recommends vertically integrating production for highly specific and critical products and applying less vertical integration for non-specific and uncritical products. In order to substitute for actual vertical ownership and direct control vertical contracts can be employed [Laf +84 , Maho92].

Hypothesis 4: If TCE and ACT hold, then less vertical integration imply the need for more vertical contracting and negotiations with external suppliers, subsequently leading to increased transaction and agency costs. These increased costs ultimately lead to a decrease in overall firm performance.

Hypothesis 5: Less vertical integration implies increased organizational and strategic risks (i.e. through dependencies on external production levels, necessary negotiations and monitoring expenses). We thus expect banks displaying a low level of vertical integration to bear increased risk in terms of betafactors and standard deviation of returns.

Production cost advantages are another influential factor determining vertical integration or sourcing decisions of corporations [AnSt98, WaWe87]. Production cost advantages are driven by economies of skill, economies of scale and economies of scope [BaPa82]. Economies of skill define the position of the cost function. Economies of scale are mainly realized by fix cost degression and learning curve effects (i.e. decreasing average unit costs when expanding the output) [ $\mathrm{BaPa} 82]$. Economies of scope are realized where it is less costly to combine two or more product lines in one firm than to produce them separately [PaWi81]. In this paper we follow the argumentation line of Berger et. al. [Ber+93], Berger and Mester [BeMe97] or Hughes et. al. [Hug+01] who detected increasing economies of scale, leading to the conclusion that larger banks are more efficient than smaller banks. For larger banks thus outsourcing does not provide any further significant impact on firm performance. Thus we assume that larger banks show less engagement in sourcing activities resulting in a higher level of vertical integration.

Hypothesis 6: Provided that economies of scale exist in banking we expect larger banks to have a higher level of vertical integration.

One of the most influential factors for capital markets is a specific company's financial performance especially future outlook and growth potential. Provided that outsourcing and vertical disintegration positively impacts firm performance, investors thus tend to overweigh shares of institutions displaying increased sourcing activities. Thus the specific company's price-book-multiple is raised.

Hypothesis 7: Investors tend to react positively on sourcing activities in banking since they are expected to lead to increased profitability of the respective institution. We thus expect banks displaying increased sourcing activities (or lower a level of vertical integration) to show higher price-book-ratios. 


\section{Sample Design and Statistical Tests}

In order to construct a measure for vertical integration we have to rely on accounting data. We chose the Bankscope database as basis for our calculations. This database contains accounting data for banks as well as stock price information which allow us to evaluate the market performance of firms with different levels of vertical integration.

We extracted a panel sample of up to 907 banks covering the timeframe 1995 to 2002 and the countries USA, Canada, Australia, UK (Anglo-Saxon), Germany, France, Spain, Italy and Switzerland (Continental European). We excluded Japan from the calculation because both, levels of vertical integration and profitability were strongly influenced by the Asian crisis in 1998 and the subsequent economic depression afterwards. Due to mergers and acquisitions the number of banks is not stable during the observation timeframe. We established a minimum threshold of total assets exceeding $1 \mathrm{bn}$ USD at least for one year during the timeframe for each bank to be eligible for the sample. In case of a merger, the acquiring bank is maintained in the sample while the target is excluded from the day of acquisition onwards. Table 1 displays the descriptive statistics for our sample. All variables relate to the total sample consisting of all banks in the respective years 1997-2002. For each bank in the sample the average number of observations is 6.1 in the total observation timeframe.

To avoid a bias of the results we used the windsorizing method to remove outliers for all important variables. We set the variable values of the top $0.5 \%$ and the bottom $0.5 \%$ of the sample to the lowest respective highest value of the percentile.

We test the hypotheses described above by running multivariate panel OLS regressions. In all regressions we have a multiple number of banks and a maximum of eight available years. In all cases we estimate fixed effects panels.

\section{Vertical Integration in the Banking Industry}

Table 2 presents the development of the vertical integration measures between 1995 and 2002. The average value for the raw vertical integration (RVI) index in our sample is $83.9 \%$ and for the adjusted vertical integration (AVI) index is $80.8 \%$. Generally, the AVI is about 3-4 percentage points lower than the RVI. This is due to the subtraction of the net income and taxes in the calculation term. The AVI dropped by 5.0 percentage points from $82.2 \%$ in 1995 to $77.2 \%$ in 2002 . This complies with our hypothesis of declining integration due to an increase in outsourcing activities and concentration on core competencies of banks in the last decade. Due to a negative trading income it is possible that banks show values of vertical integration above 1 . 
In comparison to other industries this level of vertical integration seems extraordinary high. [Madd81] derives at a raw index of vertical integration of approximately $41 \%$ in the timeframe between 1953 and 1973 for the manufacturing industry. An even more appealing example is the automobile industry. Due to the strong reliance on suppliers the industry has an even lower level of vertical integration, e.g. only $20 \%$ of the new Smart Car by DaimlerChrysler is produced internally.

Analyzing vertical integration in banking by countries displays a decline in the index over the last years (Table 3). This tendency is especially significant in Switzerland, Germany and Italy. All of these countries had a relatively high AVI in 1995. For the Anglo-Saxon countries we notice a rather stable development. The AVI for the USA declined only by 1 percentage points in the timeframe while the Canadian index increased slightly. However, the AVI for Anglo-Saxon countries lies below the value of the central European countries. This finding can be partly explained by increased outsourcing activities especially in the USA. In Europe outsourcing used to be not so common in the late 90s and has just gained pace in the last couple of years [FrGe03].

Comparing AVI of investment and commercial banks shows a higher vertical integration for the latter group, while the overall trend of vertical integration is decreasing for both bank types. Investment banks are defined as the top percentile regarding the share of commission and trading income on total operating income in our sample. Commercial banks are defined as top percentile regarding the share of interest income on total operating income. A similar approach to differentiate both bank types has been undertaken by Beitel et. al. [Bei+04]. Table 4 provides an overview for investment banks and commercial banks.

In addition to the analysis of bank types we measured the different levels of vertical integration of diversified and specialized banks. Our separation method is based on a methodology introduced by Elsas et. al. [Els +04$]$. They measure corporate diversification using a Herfindahl-Index which measures the concentration of the different income streams (interest, commission, trading and other income) as fraction of total operating income. Diversified banks will have a low Herfindahl Index because of their multiple businesses. The top percentile diversified banks (horizontally integrated) operate significantly less vertically integrated than the top percentile of specialized banks as shown in Table 5 .

Our data set provides strong evidence that the level vertical integration in the global banking industry is much higher than in other industries. In the next chapter we will extend the analysis to evaluate the value consequences of different levels of vertical integration. 


\section{$7 \quad$ Performance Effects}

\subsection{Variables}

To evaluate performance effects of vertical integration and outsourcing in the global banking industry we have conducted several panel regression analyses.

We use the accounting based performance measures pre-tax return on equity (ROE) and operating return on equity (OPROE) to determine the profitability of the banks in our sample. Additionally, we use the price/book-ratio (PB) as a proxy for the shareholder value consequences. Price/book is defined as market value of the banks equity over the book value of the equity. A higher P/B indicates a higher valuation of the company on stock markets. Obviously the use of this ratio reduces the sample size as it can only be determined for listed companies. Especially in Europe the fraction of listed banks is much smaller than in the USA. To evaluate the consequences of different levels of vertical integration on the cost and risk structure, we use the ratio of costs to assets as a proxy for the cost structure and the standard deviation of the banks ROE of the last four years as dependent variable regarding the risk.

In addition to the measures for vertical integration (adjusted index, AVI) and outsourcing activities we include several control variables into the regression to separate and control for the influence of vertical integration and outsourcing on the dependent variables.

In order to account for risks that banks bear, we include operating leverage (OPLEV) as a measure for business risk and the equity/asset ratio as a measure for financial risk into our model. To combine the two effects it is useful to control for the standard deviation of the ROE as a measure for total risk. Because this measure requires the ROE of at least four to five years the sample size would be decreased significantly. We therefore calculated two models for each dependent variable to avoid misinterpretations. To measure the varying degree of risk in the credit portfolio we controlled for the ratio of loan loss provisions to total loans.

To control for operating efficiency we used for different levels of the cost/incomeratio (ratio of total operating costs over total operating income). Additionally we included the variable size $(\log ($ assets $))$ to account for the consequences of different scale of businesses.

Due to the fact that a high vertical integration is often associated with a high degree of diversification we explicitly controlled for diversification. To measure a bank's diversification we use the Herfindahl-index introduced in section 5 .

To shed further light on the interrelation between outsourcing and vertical integration we analyzed outsourcing activities of the banks in the sample. We relied on data also used in a study by Friedrich and Gellrich [FrGe03] which contains out- 
sourcing deals of the global banking industry between 1996 and 2002. All included outsourcing deals have a contract value of at least 10m USD.

\subsection{Results}

As stated in Hypothesis 1 we expect that outsourcing activities result in lower levels of vertical integration. Table 6 shows that the dummy variable for outsourcing activities has a negative coefficient which is significant at the $99 \%$ confidence level. Thus our data set does provide support for Hypothesis 1. Another interesting finding in the table is the relationship between specialization and vertical integration. The coefficient for the Herfindahl-index income is positive and significant. Thus specialized banks tend to be more vertically integrated.

According to Hypothesis 2 and Hypothesis 3 we expected on one hand that increased outsourcing activities or less vertical integration and a bank's profitability are positively correlated. On the other hand, Hypothesis 4 postulates higher transaction costs for less vertical integrated banks leading to an overall decrease in profitability. Table 7 (models 1-4) shows two panel regression models displaying the dummy variable for outsourcing activities and the adjusted vertical integration (AVI) index and their effect on profitability measures (Operating ROE and ROE). We included the square of the vertical integration index (AVI2) to account for a possible non-linearity of the variable. We detect no significant influence of outsourcing activities on the profitability of a bank. Thus we have to reject Hypothesis 2 .

AVI and AVI2 have a significant impact on both, OpROE and ROE. Interpreting the two variables shows a favourable effect of vertical integration for highly integrated and highly disintegrated banks. The banks that are "stuck in the middle" display the lowest profitability measures. The favourable effect for the highly integrated banks can be explained by decreased transaction cost and agency cost due to the limited dependency on suppliers. These cost savings outweigh increased production costs and the possibility that these banks are not as flexible on the costs side compared to vertically disintegrated banks. The argumentation line for highly disintegrated banks is vice versa: vastly relying on outside suppliers results in a more flexible cost structure and thus benefits their profitability. This positive effect outweighs higher transaction costs, agency costs and potential moral hazard issues due to asymmetric information between the bank and the supply side. Banks that have only an average (or mediocre) level of vertical integration are not able to exploit the benefits of either vertical integration or disintegration. Our results for hypotheses 3 and 4 are somehow ambiguous: For highly disintegrated banks our findings support Hypothesis 3, for highly integrated banks our findings support Hypothesis 4 . The average AVI in our sample is 80.9 per cent. The lowest profitability can be detected for banks having an AVI between $54-60$ per cent. 
Only 84 banks in our sample have an AVI less than 54 per cent. These banks are mostly direct brokers or internet banks, as well as pure transaction banks.

Following our results we derive two successful business models - the "fullcontrol"-model and the "network"-model. "Full control" relates to highly integrated banks that benefit from standardized, streamlined and homogenous processes, products and interfaces. Due to their integrated organizational form they exert high levels of control thus benefiting from homogeneous and less complex communication and workflows. The "network" model on the other hand relates to banks working on a very low level of vertical integration. These organizations benefit from similar efficient production structures, processes, interfaces to their external suppliers and products. In order to provide best-of-breed products regarding service and quality to their customers these organizations have to be able to communicate quickly with their external suppliers and adapt immediately to changes in the external vendor universe. Nonetheless one has to keep in mind that the overall level of standardization and commoditization of process chains and products in the banking industry is much lower than e.g. in the chemical or manufacturing industry. Ultimately this still leads to over-proportional costs of transacting, contracting and monitoring in the banking industry. It seems that the often referred term of "industrializing the banking industry" is not easy to implement and when comparing the banking industry to other industry role models one needs to bear in mind the complexity of process chains and the challenges to integrate and standardize. Consequently, as our findings implicate, banks should strive for more standards and homogenization of processes and products, even if they are currently working on a profitable basis.

Hypothesis 5 suggests that lower levels of vertical integration should be associated with higher levels of risk due to higher uncertainty regarding external partners, less potential for control and increased propensity of moral hazard. Model 5 in Table 7 shows the according regression. We used the standard deviation of the ROE as measure for the total risk of the bank. In our data we find significant relationship between vertical integration and risk.

According Hypothesis 6 we expected larger banks to be more vertically integrated due to the reason that they have already achieved a reasonable size allowing them to fully exploit economies of scale. In contradiction to this, smaller banks should more rely on other means of achieving this production cost economies. Our results support this hypothesis (see Table 6). The coefficient of the variable $\log$ (assets), which corresponds to the size of the bank, has a positive sign and is highly significant. Thus, our data supports the hypothesis that larger banks have a higher level of vertical integration.

Our final Hypothesis 7 suggests that shortening the value chain by vertical disintegration should positively affect investor's reaction on stock markets. Thus we conduct regression analysis of the adjusted vertical integration index and the dummy variable for outsourcing activities on the average price/book-ratio of the 
banks. Results are presented in Table 7 (model 5 and 6). Our findings provide evidence for a significant interrelationship between vertical integration and market valuation. Basically, we derive at the same result as for the profitability measures. Highly integrated and highly disintegrated banks experience a positive impact on $\mathrm{P} / \mathrm{B}$. Thus, in order to be rewarded by capital markets, banks need to define and communicate clear strategic objectives: Operate either on a highly integrated or highly disintegrated basis, but avoid to be stuck in the middle. Thus we can not find clear support in our data set regarding Hypothesis 7.

\section{Discussion and Conclusion}

As Maddigan and Zaima [MaZa85] point out, the way vertical integration is measured does affect the interpretation of the optimal degree of integration.

Our results provide strong and convincing evidence as well as strategic advice for banks how to shape and align their organizational structures. Outsourcing is one way to influence a firm's vertical integration - but it is not an end in itself. Banks operating on an either highly integrated or highly disintegrated level are rewarded both in terms of superior financial performance and capital market valuation. Characteristics and determinants under which these firms operate are to some extent similar: Processes are streamlined, standardized and show low complexity, interfaces (either internal or to outside suppliers) are integrated, homogenous and standardized resulting in superior services and products for their customers. Banks that are currently "stuck in the middle" in terms of their vertical integration need to define and communicate viable strategic objectives - either fully "control" operations or engage in "networking" organizations relying heavily on outside suppliers.

Being restricted to publicly available balance sheet data of the banks in our sample, we had to pursue the pragmatic approach of employing VAS as the only available measurement concept. Further research is needed in order to provide other measurement concepts for the banking industry thus enabling a more comprehensive definition of the "optimal" degree of vertical integration. Another subject for future work is the interrelation between VAS and the influencing variables. One could assume that the main driver is labour expenses which can mainly be influenced by sourcing activities of the respective bank. 


\section{References}

[Adel55] M. A. Adelman: Concept of Statistical Measurement of Vertical Integration. in G. J. Stigler, ed.: Business Concentration and Price Policy. Princeton University Press: Princeton, 1955.

[AnSt98] S. Ang and D. Straub: Production and Transaction Economies and IS Outsourcing: A Study of the U.S. Banking Industry. MIS Quarterly 4, 1998: pp. 535-552.

[BaPa82] W. J. Baumol and J. C. Panzar: Contestable Markets and the Theory of Industry Structure. Harcourt Brace Jovanovich, Inc.: New York, 1982.

[Barn91] J. Barney: Firm Resources and Sustained Competitive Advantage. Journal of Management 17, 1991: pp. 99-120.

[Barr88] P. Y. Barreyre: The Concept of "Impartition" Policies: A different Approach to Vertical Integration Strategies. Strategic Management Journal 9, 1988: pp. 507-520.

[Bart98] S. M. Bartell: Information Systems Outsourcing: A Literature Review and Agenda for Research. International Journal of Organizational Theory and Behavior 1, 1998: pp. 17-44.

[Bei+04] P. Beitel, D. Schiereck and M. Wahrenburg: Explaining the M\&A-Success in European Bank Mergers and Acquisitions. European Financial Management 10, 2004: pp. 109-132.

[BeMe97] A. N. Berger and L. J. Mester: Inside the Black Box: What explains Differences in the Efficiencies of Financial Institutions? Federal Reserve Bank of Philadephia Working Paper Series, 1997.

[Ber+93] A. N. Berger, T. H. Hancock and D. B. Humphrey: Bank Efficiency derived from the Profit Function. Jounal of Banking and Finance 17, 1993: pp. 317-347.

[Buzz83] R. D. Buzzell: Is Vertical Integration Profitable? Harvard Business Review 61, 1983: pp. 92-102.

[CaBr88] R. E. Caves and R. M. Bradburd: The Empirical Deteminants of Vertical Integration. Journal of Economic Behavior 9, 1988: pp. 265-279.

[Cald03] B. M. Caldwell: IT Outsourcing Contracts: Crunching the Numbers. Gartner Dataquest Research Brief, 2003.

[CaYo03] B. M. Caldwell and A. Young: Outsourcing Still the Bright Spot in IT Services. Gartner Dataquest Alert, 2003.

[Che+95] M. J. Cheon, V. Grover and J. T. C. Teng: Theoretical Perspectives on the Outsourcing of Information Systems. Journal of Information Technology 10, 1995: pp. 209-220.

[ClCa77] T. C. Clevenger and G. R. Campbell: Vertical Organization: A Neglected Element in Market Structure-Performance Models. Industrial Organization Review 5, 1977: pp. 60-66.

[Coas37] R. H. Coase: The Nature of the Firm. Economica 4, 1937: pp. 386-405. 
[DaI192] R. A. D'Aveni and A. V. Illinitch: Complex Patterns of Vertical Integration in the Forest Products Industry: Systematic and Bankruptcy Risk. Academy of Management Journal 35, 1992: pp. 596-625.

[DaMo95] S. W. Davies and C. Morris: A New Index of Vertical Integration: Some Estimates for UK Manufacturing. International Journal of Industrial Organization Vol. 13, 1995: pp. 151-177.

[DaRa94] R. A. D'Aveni and D. J. Ravenscraft: Economies of Integration versus Bureaucracy Costs: Does Vertical Integration Improve Performance. The Academy of Management Journal 37, 1994: pp. 1167-1206.

[Els+04] R. Elsas, A. Hackethal and M. Holzhäuser: The anatomy of Universal Banking. 2004.

[FiSi99] D. J. Fixler and D. Siegel: Outsourcing and Productivity Growth in Services. Structural Changes and Economic Dynamics 10, 1999: pp. 177-194.

[FrGe03] L. Friedrich and T. Gellrich: Capital Market Reaction to Financial Services Outsourcing. Working Paper, 2003.

[FuMe99] O. Fuerst and N. D. Melumad: Consider Outsourcing Even What You Do Best. Working Paper, 1999.

[GiRa00] K. M. Gilley and A. Rasheed: Making More by Doing Less: An Analysis of Outsourcing and its Effects on Firm Performance. Journal of Management Vol. 26, 2000: pp. 763-790.

[Gort62] M. Gort: Diversification and Integration in American Industry. Princeton University Press: Princeton, 1962.

[GöSt02] B. Görzig and A. Stephan: Outsourcing and Firm-level Performance. DIW Berlin, 2002.

[Gran91] R. M. Grant: The Resource-Based Theory of Competitive Advantage: Implications for Strategy Formulation. California Management Review 33, 1991: pp. 114-135.

[Green74] J. R. Green: Vertical Integration and Assurance of Markets. Discussion Paper No. 383, 1974.

[Harr84] K. R. Harrigan: Formulating Vertical Integration Strategies. Academy of Management Review 9, 1984: pp. 638-652.

[Harr85] K. R. Harrigan: Vertical Integration and Corporate Strategy. Academy of Management Journal 28, 1985: pp. 397-425.

[Hug+01] J. P. Hughes, L. J. Mester and C.-G. Moon: Are Scale Economies in Banking Elusive or Illusive? Evidence Obtained by Incorporating Capital Structure and RiskTaking into Models of Bank Production. Journal of Banking and Finance 25, 2001: pp. 2169-2208.

[JeMe76] M. C. Jensen and W. H. Meckling: Theory of the Firm: Managerial Behaviour, Agency Costs and Ownership Structure. Journal of Financial Economics 3, 1976: pp. 305-360. 
[JoHi88] G. R. Jones and C. W. L. Hill: Transaction Cost Analysis of Strategy-Structure Choice. Journal of Management 23, 1988: pp. 159-172.

[KiLa03] S. Kinkel and G. Lay: Fertigungstiefe - Ballast oder Kapital? Mitteilungen aus der Produktionsinnovationserhebung, 2003.

[Laf +84$]$ R. N. Lafferty, R. H. Lande and J. B. Kirkwood: Impact Evaluations of Federal Trade Commission Vertical Restraint Cases. 1984.

[Laff69] A. B. Laffer: Vertical Integration by Corporations. The Review of Economics and Statistics Vol. 51, 1969: pp. 91-93.

[Leon51] W. W. Leontieff: The Structure of American Economy 1919-1939. Oxford University Press: New York, 1951.

[Levy85] D. T. Levy: The Transactions Cost Approach to Vertical Integration: An Empirical Examination. The Review of Economics and Statistics Vol. 67, 1985: pp. 438-445.

[Lieb91] M. B. Lieberman: Determinants of Vertical Integration: An Empirical Test. The Journal of Industrial Economics 39, 1991: pp. 451-466.

[Luk+02] M. Lukacs, M. Friend and J. Snowdon: European Business Process Outsourcing Forecast and Analysis 2001-2006. IDC Report, 2002.

[Madd81] R. J. Maddigan: The Measurement of Vertical Integration. The Review of Economics and Statistics Vol. 63, 1981: pp. 328-335.

[Maho89] J. T. Mahoney: Organizational Rationalization and Innovation: Vertical Integration and Multidivisional Organization. Wharton School. University of Pennsylvania: Philadelphia, PA, 1989.

[Maho92] J. T. Mahoney: The Choice of Organizational Form: Vertical Financial Ownership Versus Other Methods of Vertical Integration. Strategic Management Journal 13, 1992: pp. 559 - 584.

[Mart86] S. Martin: Causes and Effects of Vertical Integration. Journal of Applied Economics 18, 1986: pp. 737-755.

[MaZa85] R. J. Maddigan and J. K. Zaima: The Profitability of Vertical Integration. Managerial and Decision Economics 6, 1985: pp. 178-179.

[Mpoy03] R. T. Mpoyi: The Impact of Industry Characteristics on Vertical Integration Strategies. Journal of the Academy of Business and Economics April, 2003: pp.

[Nels63] R. L. Nelson: Concentration in the Manufacturing Industries of the United States. Yale University Press: New Haven, 1963.

[Pale85] K. Palepu: Diversification Strategy, Profit Performance and the Entropy Measure. Strategic Management Journal 6, 1985: pp. 239-255.

[PaWi81] J. C. Panzar and R. D. Willig: Economies of Scope. The American Economic Review Vol. 71, 1981: pp. 268-272.

[Perr80] M. K. Perry: Forward Integration by Alcoa: 1888-1930. Journal of Industrial Economics 29, 1980: pp. 159-170. 
[Port80] M. A. Porter: Competitive Strategy: Techniques for Analyzing Industries and Competitors. Free Press: New York, 1980.

[PrHa90] C. K. Prahalad and G. Hamel: The Core Competence of the Corporation. Harvard Business Review 68, 1990: pp. 79-91.

[QuHi94] J. B. Quinn and F. G. Hilmer: Strategic Outsourcing. Sloan Management Review 35, 1994: pp. 43-55.

[Qui+90] J. B. Quinn, T. L. Doorley and P. C. Paquette: Technology in Services: Rethinking Strategic Focus. Sloan Management Review 31, 1990: pp. 79-87.

[ReFr90] R. Reed and M. P. Fronmueller: Vertical Integration: A Comparative Analysis of Performance and Risk. Managerial and Decision Economics Vol.11, 1990: pp. 177-185.

[Ross73] S. A. Ross: Economic Theory of Agency: The Principal Problem. American Economic Review 63, 1973: pp. 134-139.

[Rume74] R. P. Rumelt: Strategy, Structure, and Economic Performance. Harvard University Press: Cambridge, 1974.

[Rume82] R. P. Rumelt: Diversification Strategy and Profitability. Strategic Management Journal 3, 1982: pp. 359-370.

[SaSc83] S. C. Salop and D. T. Scheffman: Raising Rivals' Costs. American Economic Review 73, 1983: pp. 267-271.

[TuWi77] I. B. Tucker and R. P. Wilder: Trends in Vertical Integration in the U.S. Manufacturing Sector. The Journal of Industrial Economics Vol. 26, 1977: pp. 81-94.

[VeGr71] J. M. Vernon and D. A. Graham: Profitability of Monopolization by Vertical Integration. Journal of Political Economy 79, 1971: pp. 924-925.

[Vese78] J. Vesey: Vertical Integration: Its Effects on Business Performance. Managerial Planning 26, 1978: pp. 11-15.

[ViWa91] J. Vickers and M. Waterson: Vertical Relationships: An Introduction. The Journal of Industrial Economics 39, 1991: pp. 445-450.

[WaWe87] G. Walker and D. Weber: Supplier Competition, Uncertainty, and Make-OrBuy Decisions. Academy of Management Journal 30, 1987: pp. 589-596.

[West81] F. M. Westfield: Vertical Integration: Does Product Price rise or fall? American Economic Review 71, 1981: pp. 334-346.

[Will71] O. E. Williamson: The Vertical Integration of Production: Market Failure Considerations. American Economic Review 61, 1971: pp. 112-123.

[Will75] O. E. Williamson: Markets and Hierarchies: Analysis and Antitrust Implications. Free Press: New York, 1975.

[Will79] O. E. Williamson: Transaction-Cost Economics: The Governance of Contractual Relations. Journal of Law and Economics 22, 1979: pp. 233-261.

[Will81] O. E. Williamson: The Economics of Organization: The Transaction Cost Approach. American Journal of Sociology 87, 1981: pp. 548-577. 
[WiTu84] R. P. Wilder and I. B. Tucker: Trends in Vertical Integration: Reply. The Journal of Industrial Economics 32, 1984: pp. 391-392.

\section{Appendix}

\begin{tabular}{lccccc}
\hline & Obs & Mean & Std.Dev. & Min & Max \\
\hline ROE & 5504 & 0.213 & 0.115 & -0.306 & 0.728 \\
OPROE & 5504 & 0.163 & 0.121 & -0.764 & 0.595 \\
Price/Book & 1624 & 2.020 & 1.590 & 0.090 & 11.720 \\
Raw vertical integration & 5504 & 0.840 & 0.091 & 0.313 & 1.153 \\
Adjusted Vertical integration & 5504 & 0.809 & 0.103 & 0.290 & 1.220 \\
Involved in Outsourcing Activities & 5504 & 0.025 & 0.156 & 0.000 & 1.000 \\
Herfindahl Index Income & 5504 & 0.723 & 0.140 & 0.288 & 1.000 \\
Cost/income & 5504 & 0.638 & 0.153 & 0.225 & 1.556 \\
log(assets) & 5504 & 8.735 & 1.673 & 0.786 & 14.002 \\
Equity/assets & 5504 & 0.079 & 0.038 & 0.013 & 0.287 \\
St.Dev. ROE & 2563 & 0.048 & 0.124 & 0.002 & 1.226 \\
LLP/loans & 5504 & 0.003 & 0.056 & -0.753 & 0.122 \\
Dummy for Commercial bank & 5504 & 0.099 & 0.299 & 0.000 & 1.000 \\
Dummy for Investment bank & 5504 & 0.079 & 0.270 & 0.000 & 1.000 \\
Dummy for 2002 & 5504 & 0.096 & 0.295 & 0.000 & 1.000 \\
Dummy for 2001 & 5504 & 0.136 & 0.342 & 0.000 & 1.000 \\
Dummy for 2000 & 5504 & 0.141 & 0.348 & 0.000 & 1.000 \\
Dummy for 1999 & 5504 & 0.142 & 0.349 & 0.000 & 1.000 \\
Dummy for 1998 & 5504 & 0.130 & 0.337 & 0.000 & 1.000 \\
Dummy for 1997 & 5504 & 0.126 & 0.332 & 0.000 & 1.000 \\
Dummy for 1996 & 5504 & 0.118 & 0.323 & 0.000 & 1.000 \\
Dummy for 1995 & 5504 & 0.112 & 0.315 & 0.000 & 1.000 \\
\hline
\end{tabular}

Table 1: Sample descriptive statistics

\begin{tabular}{lcccccccccc}
\hline & Average & $\mathbf{1 9 9 5}$ & $\mathbf{1 9 9 6}$ & $\mathbf{1 9 9 7}$ & $\mathbf{1 9 9 8}$ & $\mathbf{1 9 9 9}$ & $\mathbf{2 0 0 0}$ & $\mathbf{2 0 0 1}$ & $\mathbf{2 0 0 2}$ & $\begin{array}{c}\text { ppt.change } \\
\text { 95-02 }\end{array}$ \\
\hline Raw vertical integration index & $83.9 \%$ & $85.0 \%$ & $84.2 \%$ & $84.7 \%$ & $83.9 \%$ & $83.7 \%$ & $84.8 \%$ & $83.7 \%$ & $81.5 \%$ & $-3.5 \%$ \\
Adjusted vertical integration index & $80.8 \%$ & $82.2 \%$ & $81.3 \%$ & $81.8 \%$ & $80.8 \%$ & $80.2 \%$ & $81.9 \%$ & $80.9 \%$ & $77.2 \%$ & $-5.0 \%$ \\
$\mathrm{~N}$ & & 615 & 649 & 695 & 717 & 780 & $\mathbf{7 7 4}$ & $\mathbf{7 4 6}$ & 528 & \\
\hline
\end{tabular}

Table 2: Development of vertical integration

\begin{tabular}{lccccccccc}
\hline & share of obs. & $\mathbf{1 9 9 5}$ & $\mathbf{1 9 9 6}$ & $\mathbf{1 9 9 7}$ & $\mathbf{1 9 9 8}$ & $\mathbf{1 9 9 9}$ & $\mathbf{2 0 0 0}$ & $\mathbf{2 0 0 1}$ & $\mathbf{2 0 0 2}$ \\
\hline USA & $45.7 \%$ & $80.6 \%$ & $80.6 \%$ & $82.0 \%$ & $81.3 \%$ & $81.5 \%$ & $82.8 \%$ & $81.6 \%$ & $79.6 \%$ \\
Canada & $1.2 \%$ & $88.2 \%$ & $74.0 \%$ & $73.7 \%$ & $74.1 \%$ & $74.6 \%$ & $77.1 \%$ & $75.7 \%$ & $76.7 \%$ \\
Australia & $2.8 \%$ & $87.7 \%$ & $87.0 \%$ & $85.9 \%$ & $84.0 \%$ & $82.7 \%$ & $83.8 \%$ & $82.6 \%$ & $80.0 \%$ \\
UK & $10.8 \%$ & $85.0 \%$ & $83.7 \%$ & $84.4 \%$ & $85.4 \%$ & $84.1 \%$ & $85.3 \%$ & $83.5 \%$ & $81.1 \%$ \\
\hline Average anglo-saxon & & $\mathbf{8 5 . 4 \%}$ & $\mathbf{8 1 . 3} \%$ & $\mathbf{8 1 . 5} \%$ & $\mathbf{8 1 . 2 \%}$ & $\mathbf{8 0 . 7 \%}$ & $\mathbf{8 2 . 3 \%}$ & $\mathbf{8 0 . 9 \%}$ & $\mathbf{7 9 . 4 \%}$ \\
\hline Germany & $7.1 \%$ & $87.9 \%$ & $86.5 \%$ & $87.2 \%$ & $84.8 \%$ & $84.0 \%$ & $83.3 \%$ & $83.1 \%$ & $83.7 \%$ \\
France & $14.2 \%$ & $88.9 \%$ & $86.6 \%$ & $87.2 \%$ & $85.7 \%$ & $84.2 \%$ & $84.9 \%$ & $85.4 \%$ & $83.9 \%$ \\
Switzerland & $2.5 \%$ & $82.5 \%$ & $82.1 \%$ & $79.9 \%$ & $79.8 \%$ & $80.6 \%$ & $82.5 \%$ & $79.7 \%$ & $69.2 \%$ \\
Spain & $8.4 \%$ & $89.3 \%$ & $86.4 \%$ & $83.7 \%$ & $82.0 \%$ & $81.4 \%$ & $87.0 \%$ & $86.6 \%$ & $85.5 \%$ \\
Italy & $7.3 \%$ & $87.7 \%$ & $87.0 \%$ & $85.9 \%$ & $84.0 \%$ & $82.7 \%$ & $83.8 \%$ & $82.6 \%$ & $80.0 \%$ \\
\hline Average continental europe & & $\mathbf{8 7 . 3} \%$ & $\mathbf{8 5 . 7} \%$ & $\mathbf{8 4 . 8} \%$ & $\mathbf{8 3 . 3} \%$ & $\mathbf{8 2 . 6 \%}$ & $\mathbf{8 4 . 3} \%$ & $\mathbf{8 3 . 5} \%$ & $\mathbf{8 0 . 5} \%$ \\
\hline
\end{tabular}

Table 3: International comparison of vertical integration (AVI)

\begin{tabular}{lcccccccc}
\hline & $\mathbf{1 9 9 5}$ & $\mathbf{1 9 9 6}$ & $\mathbf{1 9 9 7}$ & $\mathbf{1 9 9 8}$ & $\mathbf{1 9 9 9}$ & $\mathbf{2 0 0 0}$ & $\mathbf{2 0 0 1}$ & $\mathbf{2 0 0 2}$ \\
\hline Investment Bank & $84.2 \%$ & $79.6 \%$ & $81.0 \%$ & $80.4 \%$ & $79.6 \%$ & $82.1 \%$ & $79.7 \%$ & $76.3 \%$ \\
Commercial Bank & $90.8 \%$ & $89.8 \%$ & $90.0 \%$ & $89.6 \%$ & $87.3 \%$ & $90.2 \%$ & $91.5 \%$ & $88.7 \%$ \\
\hline
\end{tabular}

Table 4: Vertical integration of investment and commercial banks (AVI) (top and bottom percentile) 


\begin{tabular}{lcccccccc}
\hline & $\mathbf{1 9 9 5}$ & $\mathbf{1 9 9 6}$ & $\mathbf{1 9 9 7}$ & $\mathbf{1 9 9 8}$ & $\mathbf{1 9 9 9}$ & $\mathbf{2 0 0 0}$ & $\mathbf{2 0 0 1}$ & $\mathbf{2 0 0 2}$ \\
\hline Diversified Banks & $77.2 \%$ & $75.6 \%$ & $76.8 \%$ & $75.6 \%$ & $75.8 \%$ & $77.4 \%$ & $73.5 \%$ & $68.5 \%$ \\
Specialized Banks & $90.9 \%$ & $89.5 \%$ & $89.2 \%$ & $89.1 \%$ & $86.7 \%$ & $88.9 \%$ & $88.6 \%$ & $86.2 \%$ \\
\hline
\end{tabular}

Table 5: Vertical integration of specialized vs. diversified banks (AVI) (top and bottom percentile)

\begin{tabular}{lcc}
\hline & Adjusted Vertical integration \\
\hline Involved in Outsourcing Activities & -0.027 & $* * *$ \\
Herfindahl Index Income & 0.151 & $* * *$ \\
log(assets) & 0.017 & $* * *$ \\
Dummy for Investment bank & 0.005 & \\
Dummy for Commercial bank & 0.013 & $* * *$ \\
Dummy for 2002 & -0.031 & $* * *$ \\
Dummy for 2001 & -0.005 & \\
Dummy for 2000 & 0.005 & $* * *$ \\
Dummy for 1999 & -0.011 & $* *$ \\
Dummy for 1998 & -0.007 & $*$ \\
Dummy for 1997 & -0.001 & $* * *$ \\
Dummy for 1996 & -0.006 & \\
Constant & 0.552 & \\
& & \\
N & 5504 & $* * *$ \\
Groups & 907 & \\
$\mathrm{R}^{2}$ & 0.0867 & \\
F-Test & 36.29 & \\
\hline
\end{tabular}

Table 6: Outsourcing and vertical integration: panel regression 1995-2002

\begin{tabular}{|c|c|c|c|c|c|c|c|c|c|c|c|c|c|c|}
\hline & $\begin{array}{c}\text { Model 1 } \\
\text { ROE } \\
\end{array}$ & & $\begin{array}{c}\text { Model } \\
\text { ROE }\end{array}$ & & $\begin{array}{l}\text { Model } \\
\text { OPRO }\end{array}$ & & $\begin{array}{l}\text { Model } 4 \\
\text { OPROE }\end{array}$ & & $\begin{array}{r}\text { Model } \\
\text { St.Dev. } \\
\end{array}$ & & $\begin{array}{r}\text { Model } \\
\text { Price/Bo } \\
\end{array}$ & & $\begin{array}{r}\text { Model } 7 \\
\text { Price/Boo }\end{array}$ & \\
\hline Adjusted Vertical integration & -0.515 & & -1.460 & *** & -0.910 & ${ }_{* * *}$ & -2.092 & & -0.370 & ** & -10.175 & & -5.348 & \\
\hline & 0.476 & $* * *$ & 1.081 & *** & 0.714 & *** & 1.462 & *** & 0.255 & *** & 5.825 & ** & 4.163 & * \\
\hline Involved in Outsourcing Activities & -0.001 & & -0.005 & & -0.005 & & -0.014 & & 0.014 & & 0.148 & & -0.124 & \\
\hline Herfindahl Index Income & -0.100 & *** & -0.163 & *** & -0.145 & *** & -0.221 & *** & -0.054 & & -0.767 & & -1.070 & ** \\
\hline log(assets) & -0.008 & $* * *$ & -0.016 & * & -0.014 & *** & -0.030 & $* \star *$ & -0.027 & *** & -1.994 & $* * *$ & -1.706 & *** \\
\hline Cost/income & -0.306 & $* * *$ & -0.266 & $* * *$ & -0.454 & *** & -0.424 & $* * *$ & & & -3.229 & $* \star \star *$ & -1.418 & *** \\
\hline Equity/assets & -0.046 & & -0.040 & & -0.307 & $* * *$ & -0.486 & 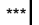 & -0.349 & *** & -20.765 & $* \star \star *$ & -16.729 & *** \\
\hline LLP/loans & -0.196 & $* * *$ & -0.306 & *** & -0.263 & $* * *$ & -0.408 & $* \star *$ & 0.081 & ** & 3.388 & $* * *$ & 7.168 & *** \\
\hline St.Dev. ROE & & & -0.271 & $* * *$ & & & -0.284 & $* * *$ & & & & & 0.139 & \\
\hline Dummy for Investment bank & 0.020 & $* * *$ & 0.036 & *** & 0.020 & ** & 0.033 & 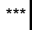 & 0.004 & & 0.158 & & 0.090 & \\
\hline Dummy for Commercial bank & -0.002 & & 0.011 & & 0.005 & & 0.023 & $* *$ & 0.005 & & 0.219 & & 0.058 & \\
\hline Dummy for 2002 & -0.015 & **** & -0.019 & & -0.030 & *** & -0.033 & * & -0.018 & & -0.029 & & & \\
\hline Dummy for 2001 & -0.008 & * & -0.013 & & -0.017 & $* * *$ & -0.023 & & -0.021 & & -0.073 & & -0.101 & * \\
\hline Dummy for 2000 & -0.001 & & -0.009 & & -0.004 & & -0.012 & & -0.024 & & -0.070 & & -0.085 & \\
\hline Dummy for 1999 & 0.006 & & -0.001 & & 0.006 & & -0.003 & & -0.032 & ** & -0.130 & & -0.088 & \\
\hline Dummy for 1998 & 0.000 & & -0.010 & & 0.000 & & -0.011 & & -0.031 & ** & 0.031 & & 0.184 & \\
\hline Dummy for 1997 & -0.001 & & -0.010 & & -0.002 & & -0.019 & & -0.014 & & & & 3.703 & *** \\
\hline Dummy for 1996 & -0.002 & & 0.018 & & -0.001 & & 0.021 & & 0.006 & & -0.710 & *** & & \\
\hline Dummy for 1995 & & & & & & & & & & & & & & \\
\hline Dummy for 1994 & & & & & & & & & & & & & & \\
\hline Dummy for 1993 & & & & & & & & & & & & & & \\
\hline Dummy for 1992 & & & & & & & & & & & & & & \\
\hline $\begin{array}{l}\text { Dummy for } 1991 \\
\text { Constant }\end{array}$ & & $\star \star \star * \mid$ & & $* * \star \mid$ & & $* * *$ & & $\star \star \star \star \mid$ & & $* * *$ & & $* * \star \Delta$ & 22459 & $* * *$ \\
\hline Constant & 0.550 & & 1.020 & & 0.974 & & 1.638 & & 0.504 & $\approx \times x$ & 29.087 & & 22.459 & $x+x$ \\
\hline $\mathrm{N}$ & 5504 & & 2563 & & 5504 & & 2563 & & 2563 & & 1624 & & 956 & \\
\hline Groups & 907 & & 730 & & 907 & & 730 & & 730 & & 357 & & 291 & \\
\hline & 0.2154 & & 0.2826 & & 0.2767 & & 0.3389 & & 0.0271 & & 0.3636 & & 0.417 & \\
\hline F-Test & 73.96 & $* * *$ & 39.72 & $* * \star$ & 103.05 & $\star * * *$ & 51.68 & $* * \star$ & 3.16 & $* * *$ & 44.67 & $\star \star \star \star$ & 29.01 & $* * *$ \\
\hline
\end{tabular}

Table 7: Vertical integration and profitability: panel regression 1995-2002

Notes: $* * * / * * *$ significant $10 / 5 / 1 \%$ level 